\title{
In vitro evaluation of fungicides and botanicals against stem rot of chilli caused by Sclerotium rolfsii
}

\author{
AMREEN BEGUM ${ }^{1}$, M.S. DADKE ${ }^{1}$, S.S. WAGH*2, D.P. KULDHAR ${ }^{2}$, D.V. PAWAR ${ }^{2}$, A.A. CHAVAN ${ }^{2}$ AND \\ D.S. THAWARE ${ }^{2}$ \\ ${ }^{1}$ Department of Plant Pathology, College of Agriculture, LATUR (M.S.) INDIA \\ ${ }^{2}$ Department of Plant Pathology, College of Agriculture, Vasantrao Naik Marathwada Krishi Vidyapeeth, PARBHANI \\ (M.S.) INDIA
}

\section{ARITCLE INFO}

$\begin{array}{ll}\text { Received } & : 07.05 .2014 \\ \text { Revised } & : 30.08 .2014 \\ \text { Accepted } & : 12.09 .2014\end{array}$

Accepted : 12.09 .2014

\section{KEY WORDS :}

Chilli, S. rolfsii, Stem rot, In vitro evaluation, Fungicides, Botanicals

*Corresponding author: Email: sandeepwagh88@gmail.com

\begin{abstract}
Stem rot caused by Sclerotium rolfsii Sacc. has been observed to cause rapid mortality in chilli plantations. Among eight fungicides and eight botanicals tested in vitro against $S$. rolfsii, the result revealed that maximum (100\%) inhibition was observed in carboxin, propiconazole, hexaconazole, difenconazole and carbendazim at all three concentrations viz., 500, 1000 and $1500 \mathrm{ppm}$ followed by captan $(79.30,82.76$ and $85.23 \%)$ and triadimenfon $(49.13,60.23$ and $65.33 \%$ ) over control. Minimum per cent of inhibition was observed in the plates poisoned with copper oxychloride $(47.26,51.63$ and $54.40 \%)$, respectively at all three concentrations. Among botanicals, at 5 and 10 per cent concentrations, significantly highest average inhibition was recorded with neem $(74.81 \%)$, followed by tulsi $(67.10 \%)$ and nirgudi $(65.81 \%)$. Significantly least average inhibition was recorded with sorghum $(47.23 \%)$. The rest of the botanicals recorded more than 50.00 per cent average inhibition of mycelial growth over untreated control $(00.00 \%)$.
\end{abstract}

How to view point the article : Begum, Amreen, Dadke, M.S., Wagh, S.S., Kuldhar, D.P., Pawar, D.V., Chavan, A.A. and Thaware, D.S. (2014). In vitro evaluation of fungicides and botanicals against stem rot of chilli caused by Sclerotium rolfsii. Internat. J. Plant Protec., 7(2) : 437-440. 